\title{
FEATURE-VIGNETTE
}

\section{Democracy in a Singapore Prison, 1825-1873}

\author{
by THOM GEHRING \\ California State University, San Bernardino
}

The British acquired Singapore in 1825, and used it, in part, as a penal colony for convicts transported from India - much as they used Australia as penal colonies for convicts transported from England. The ticket-of-leave system (parole) was used to regulate prison routines. Prisoners who earned marks for good behavior would be released early. That system was later named reformatory prison discipline. (McNair, J.R.A., and Bayliss, W.D. [1899]. Prisoners Their Own Warders: A Record of the Convict Prison at Singapore in the Straits Settlements Established 1825, Discontinued 1873, Together with a cursory history of the Convict Establishment at Bencoolen, Penang and Malacca from the Year 1797. Westminister, England: Archibald Constable and Co., p. 5). The authorities had some discretion regarding sentences and punishments, so they established various classes of prisoners, subject a range of parole sanctions. A few of the convicts were deemed ready for immediate parole. (McNair and Bayliss, 1899, p. 14). Some of the officers (warders) were civilian employees, but "an attempt was. . . made to enlist the services of well-trained convicts to oversee their fellow-prisoners;" prison regulations were revised accordingly (McNair and Bayliss, 1899, p. 19).

The two-storied prison was large, had separate quarters for female prisoners, and had such features as guards' quarters, sleeping areas, and a hospital. However, it was poorly ventilated and not well equipped with cooking places and latrines. The biggest problem was that different groups from India did not behave well when confined in the same space. Hence, the plan for using the ticket-of-leave system to have groups of convicts live in their own quarters, sometimes at great distances from the prison. They came in to report and pick up supplies periodically. This is probably why the prison was labeled democratic. (McNair and Bayliss, 1899, pp. 19-46). Eventually, the whole system of civilian officers was abolished (McNair and Bayliss, 1899, p. 19).

Convicts were engaged in different occupations during their incarceration. They were most remembered for those that directly related to the safety and prosperity of the Singapore colony. These included stone quarrying (McNair and Bayliss, 1899, p. 11) and making bricks (McNair and Bayliss, 1899, pp. 110, 174); cutting and burning down jungle vegetation, working on the roads, and leveling ground for roads and construction sites (McNair and Bayliss, 1899, p. 15); erecting public buildings such as a cathedral (McNair and Bayliss, 1899, p. 16), Government House, (McNair and Bayliss, 1899, pp. 101-104), and light houses (McNair and Bayliss, 1899, pp. 60, 62). Some helped rid the area of dangerous animals-killing wild boars (McNair and Bayliss, 1899, p. 25), and trapping tigers (McNair and Bayliss, 1899, pp. 52, 131). They dispersed Chinese rioters (McNair and Bayliss, 1899, p. pp 67-68) and worked as firefighters (McNair and Bayliss, 1899, p. 42). Some prisoners were assigned to be orderlies and servants (McNair and Bayliss, 1899, p. 42). Most were able to arrange for some extramural employment in the outside community so they could save money for their new life after release (McNair and Bayliss, 1899, pp. 108-112). After parole they often took jobs as "artizans, cow keepers, cart drivers, and the like" in local communities (McNair and Bayliss, 1899, p. 4).

Thom Gehring is the research director of the Center for the Study of Correctional Education at California State

Correspondence: Thom Gehring, Email: gehringthom@gmail.com

(Accepted: 2/27/2017) ISSN: 2387-2306 doi: http://dx.doi.org/10.15845/jper.v4i1.1185

Except where otherwise noted, content on this site is licensed under a Creative Commons Attribution 4.0 International License.

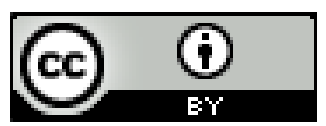


University, San Bernardino. His scholarly emphasis is on the history of correctional education and prison reform. He has been a correctional educator since 1972. Thom did his Ph.D. dissertation on the correctional school district pattern of organization. He serves as the historian for the Correctional Education Association. Thom is a professor of education who directs the EDCA correctional and alternative masters degree program. 